\title{
Analysis of Relationship of Environmental Performance and Firm Value
}

\author{
Kannya Purnamahatty Prawirasasra, SE.,MBA \\ Sekolah Tinggi Ilmu Ekonomi Ekuitas, Jl. P.H.H Mustofa No. 31, Bandung \\ kannya.prawirasasra@gmail.com \\ kannya.prawirasasra@ekuitas.ac.id
}

\begin{abstract}
Environmental has been an isuue for Indonesia, which impose threats to sustainable development, such as the impact of climate change and also energy and food crisis. Bank Indonesia as a regulator in banking industry, decided to publish the regulation about Green Banking, as an act to focus on raising awareeness and capacity building for bank, as a financial intermediary which play an important role to change the economic development.
\end{abstract}

This study analyze the relationship between Environmental performance and firm value, which is measured with Tobin's Q ratio. The sample data is obtained from 41 banks that listed in Indonesia Stock Exchanges (BEI) in the period of $2011-2013$. The methodolgy conducted in this study is multiple linear regression.

The outcome of this study indicates there is a postive relationship between environmental performance and firm value. This result is in line with previous similar studies which were based on data from other sectors in Indonesia.

Keywords: Environmental Performance, Environmental Disclosure, Environmental Management System, Firm Value

\section{Introduction}

Global Warming has been an issue and hotly debated by the world's leader since 1970 . One of the study says that human being have significantly contributed to the destruction of the nature. Through the debate, world's leader took several steps that can be done by humans as an effort to prevent the effects of the global warming.

Several International Conferences have been held to change the paradigm of thinking all parties to be jointly responsible for the protection of the environment, which can not be separated from social and economic development. Considers that the public's business activities and the company are a party that contributed the most to the problems of environmental degradation that occurs at this time.

Environmental conditions that are deteriorated and the increasing public awareness of environmental sustainability, trigger pressure on companies to pay more attention to environmental management is not just about the business continuity.
Environmental issues and the impact given to the social life put pressure on the business world. Therefore, demands for accountability for order and accuracy in the management of resources led the government to require that every company has the Environmental Management System (EMS) that is compliant with ISO standards.

There are some differences in viewpoints in assessing this case. A company that chooses to improve the environmental performance mainly causes extra costs for the firm. On the other hand, will reduce the profitability. By cons, that the increase means an austerity environment performance and will increase the company's sales level that will directly result in an increase in the economic performance of the company.

Former study have tried to do some research into the correlation between environmental performance with economic performance. Montabon (2007) concluded that there is a positive relationship between environmental performance with economic performance. 
It is also supported by research conducted by Jacob (2010) which concluded that significantly market will react positively of implementation of Environment Management System in a company. Overall, the market is selective in reacting to announcements of environmental performance with certain types of announcements even negatively valued.

\section{Literature Review}

\subsection{Relationship between environmental performance and firm value}

Former study, which use pooling as a tool, states that business activities and company as the largets contributor on environmental issues that occur today.

Another research conducted Lorraine, et. al (2004) also concluded that there is a relationship between environmental disclosure with the performance of the company (in this case the share price). The study said that several companies in the UK that has the quality of environmental reporting unfavorable decreased the mean return period 1995-2000.

Further research is also carried out by Jacob (2010) who said that there was indeed a relationship between company news related to the environment with the performance of the company (with the object of the company that is in the US).

However, Schaltegger (2002) states that not every kind of environmental management increases the economic success. This is possible because of differences in viewpoint between the implementation of green business with the costs incurred. Implementation of green business can improve the performance of the company, but on the other hand, it will require a bigger initial investment to be issued by a company.

Russo and Fouts (1997) connects between the environmental performance with economic performance with objects 243 companies measured its environmental performance by an independent company ranked providers on the environment. Results of this study concluded that the company's environmental performance is very dependent on the rate of growth itself.

Recent research conducted by Orlitzky et al. (2003) concluded that there is a positive correlation between environmental performance in manufacturing companies with economic performance using meta-analysis were then confirmed by Porter that the increase in environmental performance will automatically improve overall business performance.

\subsection{Measuring Environmental Performance}

In general, there have been some previous studies and surveys about the environmental management field. The difficulties in measuring environmental performance is evident to the many variations of the data used from the start case study, surveys, and other data (Mantabon et.al:2007).

The Indonesian Ministry of Environment forming PROPER (Program Penilaian Peringkat Kinerja Perusahaan dalam Pengelolaan Lingkungan Hidup). However, only companies that run business activities relating to natural resources that are required to conduct a social and environmental responsibility.

This program will provide further described 5 (five) ranking the color codes to describe each company starting from best to worst in environmental management: gold, green, blue, red, and black.

Because the Bank is one of the businesses that are not directly related to natural resources, the bank industry is not included into the PROPER program. Jones, et al. (1999) identified that the environmental report is one of the communications media in conveying the firm's environmental performance. Thus, the indicator is the presence of the Environmental Performance reporting on the implementation of environmental activities, in this case the reporting on the implementation of the Green Banking in the company. Although this is difficult thing to quantify.

\subsection{Measuring Firm's Value}

The indicator for the value of the company, the performance evaluation by calculating the market value of the company. The better performance of the company, then the higher the value of the company.

One method in calculating the market value of a company by comparing the value of shares outstanding in the market and book value of the company's capital, known as Tobin's Q method, hereinafter referred to as the $\mathrm{Q}$ ratio, calculated as follows:

$$
q=\frac{(M V E+P S+D e b t)}{\text { Total Asset }(B V)}
$$


where:

- MVE = Market Value of outstanding shares.

- $\mathrm{PS}=$ Liquidity Value of outstanding preferred stock.

- $\quad$ Debt $=$ Short term debt and book value of the long term debt.

The market value of the company showed a profit which may be obtained by the company. According to Lee (2003) there is a deficiency of $Q$ ratio when using the market price for the company's liabilities, then the $\mathrm{Q}$ ratio is not the right size for the viewpoint of shareholders, but it is a measure of the market value of the company from the perspective of claim's holders.

\section{Sample Data and Hypotheses}

To generate our sample, the companies involved in this study was selected from 41 banks that listed in Indonesian Stock Exchange from the period of $2012-2014$. There are several banks that haven't been listed in Indonesia Stock Exchange from 2012. So there will only 31 banks that will be used as the sample of this study.

In this study, we used validity test using Pearson's correlation (significant level of 5\%), because the data used is data that is interval or ratio. Pearson correlation test illustrates the degree of linear relationship between 2 (two) quantitative variables, and used to determine the relationship between the 2 (two) variables and to determine the direction of the relations.

After the validity test analysis by Pearson's correlation coefficient significance test, to test whether the relationship is valid for the population (can be generalized). Step in conducting tests of the significance correlation coefficients is:

1. Determine the hypotheses

2. Determining the level of significance, this study used a significance level of $5 \%$. This means that researchers take any risks as much as $5 \%$ in the decision to reject a true hypothesis.

3. Determination of criteria for testing

4. Comparing the significance. is:

Given the above discussion, our hypotheses

$\mathbf{H}_{0 .}$ The market doesn't reacts to
Environmental issue.
$\circ H_{1}$ The market reacts to
Environmental issue

Criteria in the testing analysis, namely $\mathrm{H}_{0}$ is accepted if the significance level greater than 0.05 . and conversely, $\mathrm{H}_{0}$ is rejected if the significance level of less than 0:05.

List of Banks that are used in this study, can be seen in Table. 1

Tabel. 1

Firm in this study

Bank Rakyat Indonesia Agroniaga Tbk

PT Bank MNC Internasional Tbk.

Bank Capital Indonesia Tbk

Bank Ekonomi Raharja Tbk

Bank Central Asia Tbk

Bank Bukopin Tbk

Bank Negara Indonesia Tbk

Bank Nusantara Parahyangan Tbk

Bank Rakyat Indonesia (Persero) Tbk

Bank Tabungan Negara (Persero) Tbk

Bank Mutiara Tbk

Bank Danamon Indonesia Tbk

Bank Pundi Indonesia Tbk

Bank Pembangunan Daerah Jawa Barat dan Banten

Tbk

Bank Pembangunan Daerah Jawa Timur Tbk

PT Bank QNB Indonesia Tbk

Bank Mandiri (Persero) Tbk

Bank Bumi Arta Tbk

Bank CIMB Niaga Tbk

Bank Internasional Indonesia Tbk

Bank Permata Tbk

Bank Sinarmas Tbk

Bank of India Indonesia Tbk

Bank Tabungan Pensiunan Nasional Tbk

Bank Victoria International Tbk

Bank Artha Graha Internasional Tbk

Bank Mayapada Internasional Tbk

Bank Windu Kentjana International Tbk

Bank Mega Tbk

Bank OCBC NISP Tbk

Bank Pan Indonesia Tbk

PT Bank Woori Saudara Indonesia 1906 Tbk

\section{Descriptive Statistics and Result}

The main objective of this study was to determine the relationship between environmental disclosure and firm value. The object was to test the relationship between two sets of variables with the independent variables corresponding to the Environmental Performance and the dependent variables 
corresponding to firm value. To test these hypotheses, used through bivariate correlation techniques. This technique predicts the relationship between the dependent variables from the independent variables.

Tabel. 2

The Result of Data Processing

\section{Correlations}

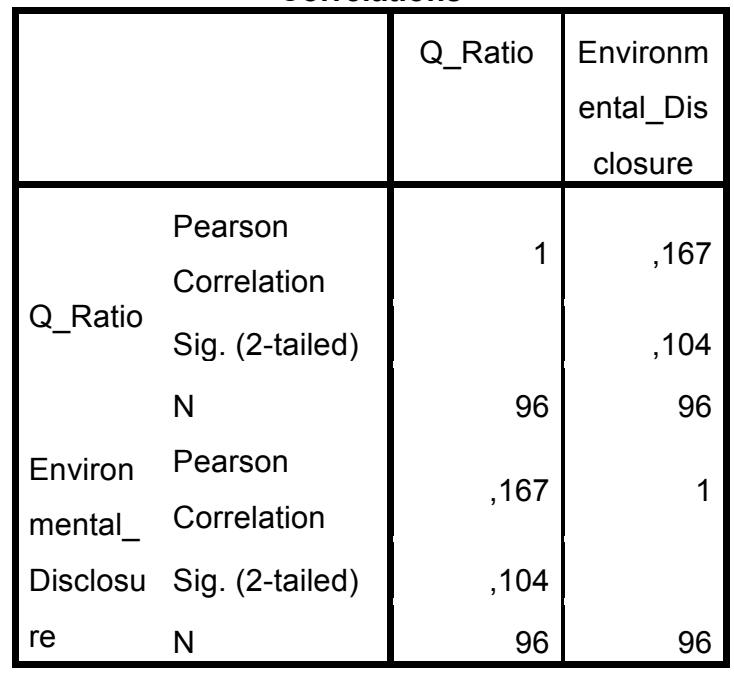

Model Summary

\begin{tabular}{|l|c|r|r|r|}
\hline $\begin{array}{l}\text { Mod } \\
\text { el }\end{array}$ & $\mathrm{R}$ & $\begin{array}{c}\mathrm{R} \\
\text { Square }\end{array}$ & $\begin{array}{r}\text { Adjusted } \\
\mathrm{R} \text { Square }\end{array}$ & $\begin{array}{c}\text { Std. Error } \\
\text { of the } \\
\text { Estimate }\end{array}$ \\
\hline 1 &, $167^{\mathrm{a}}$ &, 028 &, 018 &, 16188 \\
\hline
\end{tabular}

The results of calculations shown in the table. 2 that the value of $\mathrm{R}$ and Pearson Correlation is equal to .167 , which indicates that there is a positive relationship between the firm's environmental performance with firm value. Pearson correlation illustrates the degree of linear relationship between 2 (two) quantitative variables.

This is consistent with the results of a survey conducted by Klassen and McLaughlin (1996) states that the environmental performances are associated with the positive market reaction. When a firm's environmental performance are bad, thus correlated with the bad overall performance. It is also supported by research conducted by Lorraine (2004) which states that all forms of news related to the environment for a company will touch and affect the company's stock price.

As for testing the validity of the analysis, we can conclude that $\mathrm{H}_{0}$ is accepted because the significance value of 0104 , which show a value much greater than 0,05 . This may imply that the market reacts to environmental does not reacts to environmental issue. It can also mean that there is no significant relationship to the Firm's Environmental Performance Value.

Based on the Table. 2, the firm's environmental performance has a very weak relationship with firm value. It is also supported by the acquisition value of $\mathrm{R}$ Square is very small, amounting to 0.028 or $2.8 \%$, which means a very weak relationship also will only give effect / impact of $2.8 \%$.

Table. 3

Pedoman Interpretasi Tingkat Pengaruh

\begin{tabular}{|c|c|}
\hline $\begin{array}{c}\text { Interval } \\
\text { Koefisien }\end{array}$ & $\begin{array}{c}\text { Tingkat } \\
\text { Pengaruh }\end{array}$ \\
\hline $0.00-0.199$ & Sangat Lemah \\
\hline $0.20-0.399$ & Lemah \\
\hline $0.40-0.599$ & Cukup Kuat \\
\hline $0.60-0.799$ & Kuat \\
\hline $0.80-1.000$ & Sangat Kuat \\
\hline
\end{tabular}

Based on the Table. 2, the firm's environmental performance has a very weak relationship with firm value. It is also supported by the acquisition value of R Square is very small, amounting to 0.028 or $2.8 \%$, which means a very weak relationship also will only give effect / impact of $2.8 \%$. Thus, it can be concluded that there is a relationship between the Environmental Performance with Firm Value, but the relationship is not significant. Because of its correlation, coefficient is positive, then the firm's environmental performance has a relationship with firm value, but the significance level still greater than 0:05.

\section{Summary and Conclusion}

This study analyzed the firm value effects of environmental performance. Our analyze Cleary found that the market does not react to the firm's environment performance. However, the firm's environment performance impact of $2.8 \%$. Amounted to $97.2 \%$ firm value is influenced by several other factors that are not described in this study.

Enforcement policies regarding Green Banking has not been made by all banks in Indonesia. Only a few new ones to apply it. This can be seen from the attached environmental disclosure in the annual report is still reported around the Corporate Social Responsibility activities concerning environmental activities.

Up to now, only a few banks that have implemented Green Banking and reporting activities into the annual report. 
A limitation of this study is the changes in environmental performance may be assessed not only by the annual report, but both on Good Corporate Governance report.

Based on the results obtained from this study, that the influence exerted by environmental performance is extremely low. For further research, it can look for some other factors that affect the performance of the company, in this case measured by the $\mathrm{Q}$ ratio.

\section{References}

Jacob, Brian W., Singhal, Vinod R., Subramanian, Ravi., 2010. “An Empirical Investigation of Environmental Performance and The Market Value of The Firm" Journal of Operation Management $28,430-441$.

Jones, K., Alabaster, T., Hetherington, K., 1999. "Internet Based Environmental Reporting: Current Trends, Greener Management International" 26, 69-90

Klassen, R.D., McLaughlin, C.P., 1996. "The Impact of Environmental Management on Firm Performance". Management Science 42, 1196-1214.

Lee, Sang-Mook, "Management Ownership and Firm's Value: An Empirical Analysis Using Panel Data": 2003

Lorraine, N.H.J., Collison, D.J., Power, D.M., 2004. "An Analysis of The Stock Market Impact of Environmental Performance Information" Accounting Forum 28, 7-26.

Montabon, Frank., Sroufe, Robert., Narasimhan, Ram., 2007. "An Examination of Corporate Reporting, Environmental Management Practices and Firm Performance" Journal of Operation Management 25, 998-1014.

Orlitzky, M., Schmidt, F.L., Rynes, S.L., 2003. "Corporate Social and Financial Performance: A Meta Analysis". Organization Studies 24 (3), 403-441

Russo, M.V., Fouts, P.A., "A Resource-Based Perspective on Corporate Environmental Performance and Profitability". Academy of Management Journal 40 (3), 534-559.

Schaltegger, Stefan., Synnestvedt, Terje., 2002. "The Link Between "Green" and Economic Success: Environmental Management as The Crucial Trigger Between Environmental and Economic
Performance". Journal of Environmental Management 65, 339-346. 